\title{
Assessing Kambui Hills North Forest Reserve Community's Participation in Forest Reserve Management and Sustainability in Kenema District, Eastern Sierra Leone
}

\author{
Joseph Christian Adamu Mboma \\ Lecturer \\ Eastern Polytechnic \\ Kenema, Eastern Sierra Leone \\ jcmboma81@gmail.com
}

\begin{abstract}
This paper explores Kambui Hills North Forest Reserve (KHNFR) community's participation in forest management and sustainability in Kenema District as a case study. Crucial issues examined were the forest reserve management strategies used by forest communities, participation of stakeholders in forest sustainability and livelihood activities of forest communities in the KHNFR. For sampling technique, six (6) forest communities were randomly sampled. From the sampled communities, forty two (42) respondents were sampled from the study communities. A structured questionnaire was used to collect data from the field and focus group discussion guide. Descriptive statistics was used to analyze the data. Findings revealed that there was a Core Forest Management Plan operated by the communities and stakeholders but the District Forest Office (DFO) does not follow its prescriptions strictly. It also indicated that the involvement of forest communities in the management of KHNFR was very small and low income generating livelihood activities. It was therefore recommended that forest communities in the KHNFR should be provided with
\end{abstract}


alternative livelihood sources so as to empower them play the role of co-managers of the forest reserve.

Keywords: Forest Reserve, Kambui, Sustainability

\subsection{Introduction}

Forests consist not only of living (biotic) components like trees, animals, plants, and other living things but also of nonliving (abiotic) components such as soil, water, air, and landforms. All of these components together make up a forest ecosystem.

Forest reserves are portions of state lands where commercial harvesting of wood products is excluded in order to capture elements of biodiversity that can be missing from sustainably harvested sites. According to World Bank (2002), not less than 1 billion people depend on forests for their livelihoods at various degrees. It is not surprising that the passive integration of community livelihood activities into sustainable forest management has encouraged illegal forest harvesting since local people depend directly or indirectly on the forest for survival. More so, the weakness in deterrent legal sanctions such as low fines imposed on the perpetuators of forest offenders does not deter people. In Sierra Leone, $2,726,000$ ha or $38.1 \%$ (percent) is forested and out of which 113,000 or $4.1 \%$ (percent) is classified as primary forest with the most bio-diverse and carbon-dense form of forest in Sierra Leone. Undoubtedly from 1990-2010, on average Sierra Leone lost 19,600ha or 0.63\% per year. In total, $12.6 \%$ of its forest cover or 392,000 ha was lost (FAO, 2010). Sierra Leone is a developing country with an agrarian economy where its population is dependent on agriculture. Agents of denudation such as moving water and wind have waged havoc on forest lands due to deforestation which makes them active. Their works are characterized by unpredicted negative impacts on the livelihood of many farming and forest communities and by extension the nation as a whole. A good number of environmentally friendly organizations have committed themselves to conserve the forest and to help forest communities carry out 
best practices within the forest by maintaining its value chains from subsidiaries to suppliers. Some of the organizations have taken the path of supply chain sustainability because of its advantages. Sustainable forest conservation and supply chain management can be a good driver for the wellbeing of forest communities. Effective and efficient forest management is required to meet the increasing demand for food, fuel wood, and fibres. The alarming rate at which deforestation and land degradation mainly in forest reserves coupled with land grabbing and weak forest governance are threatening the forest ecosystem and its resources is exposed to various risks. To address these challenges in the forest communities, sustainable forest reserve management is key in responding to the challenges. Forests are destroyed at an alarming rate through various means and processes such as bush fire, indiscriminate logging, illegal and small scale mining; subsistence farming has huge negative implications on the effectiveness and efficient application of forest management strategies. It should be noted that forest contributes greatly to rural economy and dictates the livelihood strategies used for survival. To protect these reserve forests and its host forest communities, adequate forest reserve sustainable approaches needs to be adapted to realities of local needs and opportunities. Therefore it is against this backdrop that this study seeks to explore the recognition of forest reserve community's inputs and their livelihood sustenance in KHNFR in Nongowa Chiefdom, Kenema District, Eastern Sierra Leone.

\subsection{Protected Forest Area Status in Sierra Leone}

According to Blinker (2006), forest reserves and protected areas in Sierra Leone are only confined to these areas; Gola (77,044 hectares), Kambui (21,213 hectares), Dodo hills (21,185 hectares), Nimini (15,557 hectares, Freetown Peninsula (14,0899 hectares), Tama (17,094 hectares) Tonkoli (47,656 hectares), Kasewe (2,333 hectares), Loma (33,200 hectares), Sanka Biriwa (11,885 hectares), Kuru hills (7,001 hectares), and Kangari hills (8,573 hectares). The highest Forest Reserve per hectare in Sierra Leone is the Loma 
MOUNTAIN followed by the Kambui and the Dodo hills respectively. This is a clear indication that the Kambui hill forest reserve is very crucial to the development of forest communities and the country at large.

\subsection{Stakeholders Participation In Forest Reserve Management}

Well-wishers in the field of environment and environmentalist have manifested interest and concerns as to how to incorporate good ideals and knowledge of stakeholders in the management of forest and its all-important resources.

However, over the last decades the concept of stakeholders "participation" in forest reserve management has gained momentum at both local and international levels. For sustainable development to take place in impoverished rural forest communities particularly within the reserves stakeholders' participation is one of the conceptual pillars.

It has been observed by foresters, conservationists, environmentalists and rural development experts that forest fringe communities have greater influence on the forest and the forest resources for their livelihoods.

Blomley (2013) postulated that community forestry is an evolving subcategory of forestry under which communities or groups of people have partial to full rights over specific forests, including the rights to establish, implement, and enforce rules governing access and use of those forests. Conversely, these rights may be formal legal rights, or traditional or customary rights as in the case of the rights exercise by forest fringe communities in the KHNFR. For stakeholders to be effectively involved in forest reserve management, participatory forest management, community-based forest management or joint forest management can be considered to be types of community forestry if communities have rights to participate in significant decisions on how the forest is used or managed.

Ideally, community forest reserve management hinges on improving the livelihoods and welfare of the community residing therein. The forest will gain total conservation and 
management when local participation and cooperation is utilized. To achieve this, (Kotey et al, 1998) opines that, the principle of stakeholders participation therefore demands that forest fringe communities are involved in all decisions concerning the management and development of their forest resources as it will give them a better understanding and commitment to the natural resource development and protection by themselves. On this backdrop one would infer that forest management should be co-managed and maintained if not improved. The effective and efficient use of the forest therefore should be appropriately ascertained so that over exploitation should not supersede conservation but rather forest reserve management should be geared towards conserving the resource for future generations and above all for posterity.

In the words of Blomley et al. (2011and Blomley and Franks (2009), Community Based Groups (CBGs) are widely known as key stakeholders in Sustainable Forest Management. This approach of forest management is more inclusive than the widely used conventional reductionist methods of forest management, planning and advocating for the inclusion of stakeholders in decision making that affects and the forest reserves. This emphasises the fact that Community Based Groups in fringe forest communities have strong influence on sustainable forest management and have positive impacts on the reserves.

It is clear that sustainable forest management can be distorted if Community Based Groups are ignored. This would lead to conflicts of interest which would exist among the various interest groups. Therefore there should be attitudinal change of all interest groups and stakeholders of reserve forest for sustainable management of the forest by all parties. If this is not done, there would be no economic trees left, no fuel wood, no more forest product and more importantly no more nature to attract tourist for promotion of ecotourism in this part of the country. 
It is of utmost importance to sustainably manage the KHNFR so that it can perform its basic functions taken into consideration the diversity of forest management approaches and the physical properties and status of the reserve in question.

\subsection{Concept of Participatory Management}

Participation simply means being involved or being meaningfully engaged in an activity. This involves presence, relation and interactions. In the words of (Brown, 2000), participation refers to some aspect of involvement of local population in the design, implementation and evaluation of a project. To implement such participatory management process, the primary stakeholders in a project, individuals and groups of vested interest should be involved in the implementation of the project and be aware of the outcomes.

As the stakeholders in the projects are identified, collegial participation and network partnership which involves empowerment and sustainability must be established. With such partnership, all stakeholders feel comfortable and belonged to the project with their roles in the project design process to empower the resource user groups and rural organizations within which they are incorporated.

According to CFN (2008) every community is arriving at more participatory approaches to natural forest management. Primary causes of poor forest management in recent years include widening socio-political transformation in the country towards more inclusive norms in the governance of the society and its resources.

In a bid of managing forest resources, it should be borne in mind that forest governance should be made free from confusion or ambiguity with technical driven functions. If sustainable forest management is to be achieved in the KHNFR, all development plans should involve the local people in the forest communities to participates, see themselves as users and above all let their interest be captured in accessing forest land and benefits from the generated income. 
Local participation is more meaningful and effective as it made them feel as owners in their rights. When this is done it goes beyond cooperation to commitment which ensures forest sustainability.

Partnership in community forest is gradually moving away from consultative and collaborative norms so to enable the forest communities to function as independent entities. Currently the local people are looking beyond access to the forest but to be seen as custodians which is critical to any agreement with the forestry authorities.

Formete (2001) opined that it is of importance for the state to establish a tougher legal framework to establish local community's roles in forest jurisdiction. There is a need for forest administrators or managers to be transparent and accountable to the wider communities because they acting on their behalf.

This means that forest authorities or managers should be accountable especially with regards to forest resource and its usage to the wider community. This brings respect and collaboration between the managers and the forest communities.

There have been frantic efforts in African to involve forest local communities in the management of forests in their localities (Asare, 2000).

Due to these efforts, policies have been formulated with legal support through national forest policies, the forestry acts, the rural area acts, forest regulations, the draft forest acts, forest ordinance of Sierra Leone, and particularly the draft KHNFR Co- management Plan.

2.0 Study Area and Methodology

\subsection{Study Area}

The KHNFR is found in Kenema District, Eastern part of Sierra Leone. It is located some $290 \mathrm{~km}$ away from the capital Freetown. The Kambui hills form a series of plateau with 
flat tops and steep sides with variable topography running on a south west to northeast direction. It has a maximum elevation of $425 \mathrm{~m}$ above sea level.

The KNFR has a number of watersheds with numerous small streams draining into the lowland areas and its subsequent streams such as Wanje and the Lambayea respectively. It also has a lot of water catchment areas which are utilize by Sierra Leone Water Company (SALWACO) for effective water supply to Kenema City.

The reserve lies between Latitude: $7^{\circ} 51^{\prime} 20.39^{\prime \prime}$ and longitude $11^{\circ} 19.16 .20^{\prime \prime} \mathrm{W}$ the KHNFR occupies an area of 14, 335 hectares in the Eastern Province of Sierra Leone. It is also located ten (10) kilometers from the city of Kenema with terrain consisting of steep slopes that reach an altitude of between 100 and 645 meters.

Over 200 separate species of birds have been recorded in the reserve including vulnerable species such as the white-necked picarthartes and green tailed bristlebill. Some are threatened species like the yellow-casqued hornbill, rufous-winged illadopsis and coppertailed glossy-starling.

The KHNFR Reserves' climate is peculiar of tropical monsoon climate. The rain fall pattern is unevenly distributed across the forest with its heaviest precipitation received from January to September.

However the Forest Reserve experience distinct dry season from mid-November to March. The early part of this season is characterized by a dry and dusty wind locally known as the harmattan winds. 
Plate One: Map of Sierra Leone with Kambui Hills Inset

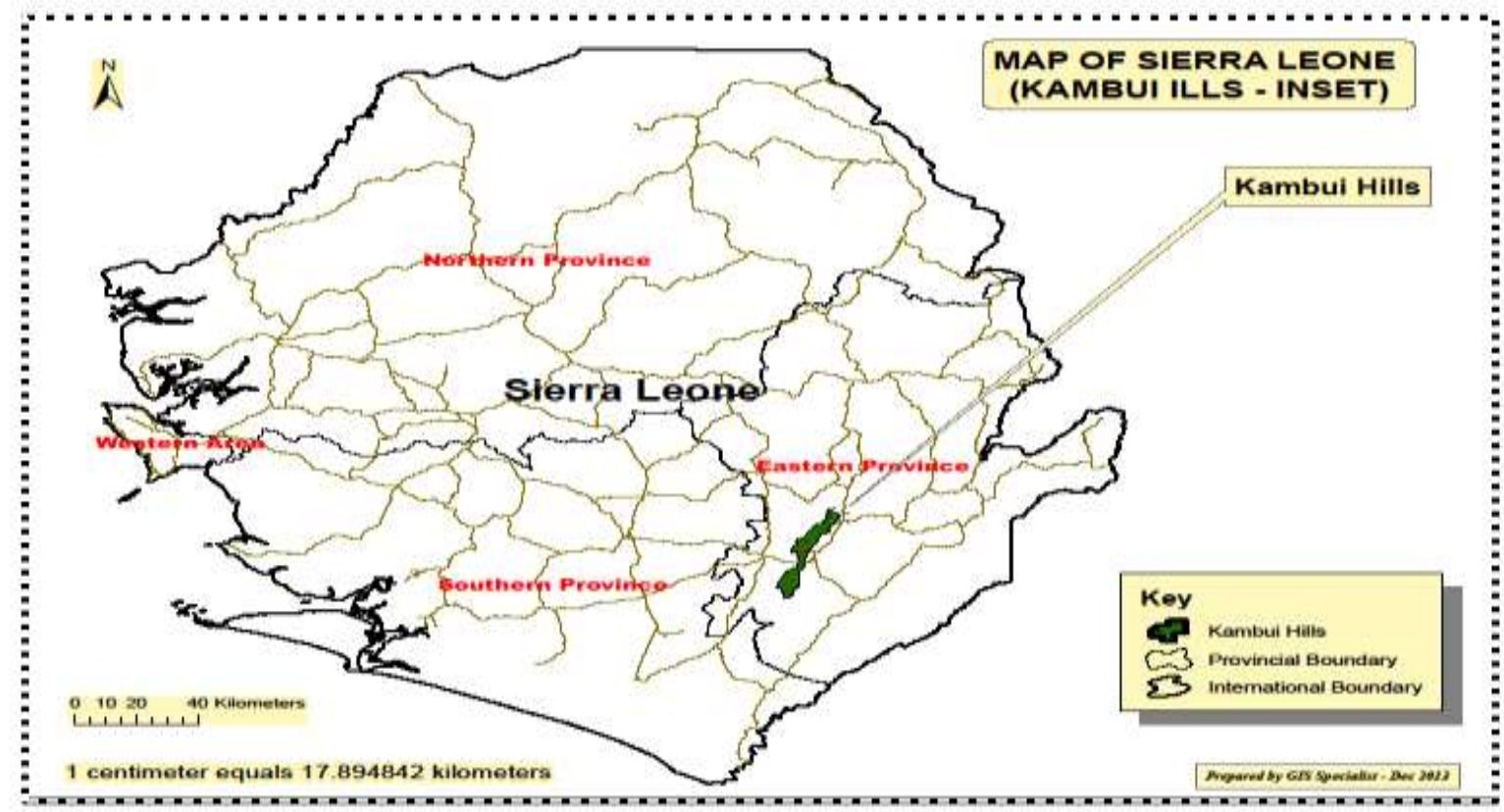

Source: Undp/Seca Project, 2013.

Plate Two: Map of Kambui Hills North Forest Rerserve

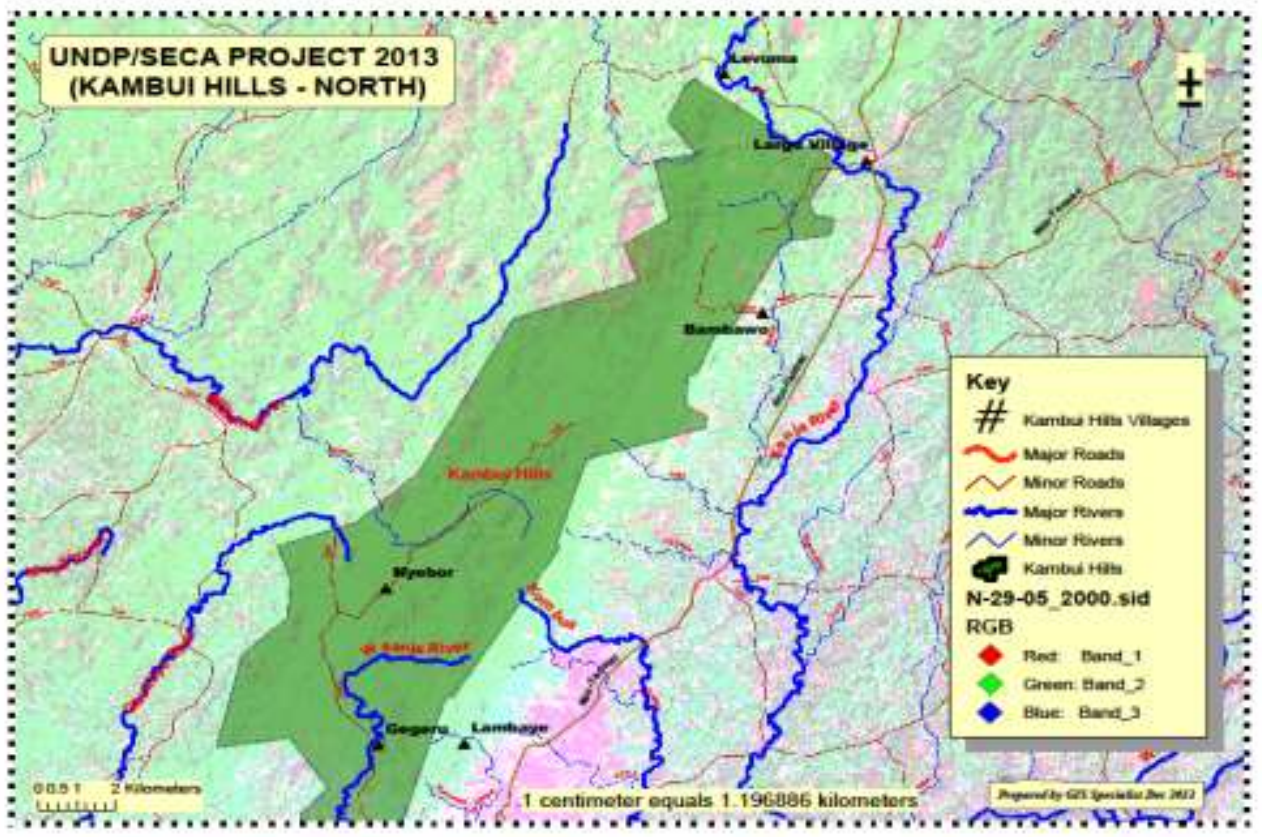

Source: Undp/Seca Project, 2013.

\subsection{Methodology}

This study used the exploratory research design. Exploratory research design is conducted about a research problem when there are few or no earlier studies to refer to or rely 
upon to predict the outcome. The main focus is on gaining insight and familiarity for later investigation undertaken when research problems are in a preliminary stage of investigation.

The main disadvantage of exploratory research design is that it provides qualitative data and interpretation of such data can be judgmental or biased. Due to the fact that an exploratory research design involves smaller samples, the result cannot be generalized for a large population.

Exploratory design is flexible and therefore can address research questions of all types (why, how, what). It can also utilize in-depth interview and focus group discussions to gather data. Above all this design helps determine the appropriate data collection methods and selection of respondents.

The study was conducted among all the relevant stakeholders within the KHNFR in Kenema District, Eastern Sierra Leone. The personnel included the District Forestry Office, Traditional Authorities, Timber Contractors, Land Owners, Stone Miners, Charcoal Burners, Gold Miners and the Fringe Communities.

Two (2) sampling procedures were used to sample the respondents. The first sampling procedure used was purposive sampling which used to select the KHNFR for the study because it had all the variables needed for the completion of this study. The other procedure used was simple random sampling of various fringe Kambui forest communities and respondents for the study.

Simple random sampling was used to select five (5) respondents each from six (6) selected communities making it thirty (30). However, the additional twelve (12) respondents were recruited from the other stakeholder's group. There were twenty-three (23) males and nineteen (19) females making the total forty-two (42) respondents. The six (6) selected communities were also randomly selected which included; Largo, Masao, Komende, Gegeru, Taninahun, and Menima fringe KHNFR Communities. 
All the selected communities had opportunity to work with UNDP/SECA and PAGE Projects from 2010-2015. Two (2) data collection methods were employed. The first was desktop literature search for secondary information and documentations on sustainability and management of forestry. The second method comprises field work which employed questionnaires, interview schedules and stakeholder consultations to obtain primary data from relevant respondents.

Data analyzes was done by the use of descriptive statistics such as frequency tables and percentages were used to present the characteristics of the respondents.

\subsection{Result And Discussion}

\subsection{Socio-Economic Characteristics Of Respondents}

\begin{tabular}{|l|l|l|}
\hline VARIABLES & FREQUENCY (N=42) & PERCETAGE (\%) \\
\hline GENDER & & \\
\hline Male & 23 & 55 \\
\hline Female & 19 & 45 \\
\hline Age (years) & & 14 \\
\hline $18-25$ & 6 & 19 \\
\hline $26-32$ & 8 & 55 \\
\hline $33-39$ & 23 & 12 \\
\hline 40 & 5 & 19 \\
\hline Level of education & 13 & 40 \\
\hline Tertiary & 4 & 31 \\
\hline Senior Secondary School & 8 & 19 \\
\hline Junior secondary School & 17 & \\
\hline No Formal education & 13 & \\
\hline
\end{tabular}




\begin{tabular}{|l|l|l|}
\hline Occupation & & \\
\hline Farming & 31 & 74 \\
\hline Trading & 3 & 7 \\
\hline Others & 8 & 19 \\
\hline
\end{tabular}

SOURCE: Field Data, 2021.

Table one: socio-economic characteristics of respondents.

Table one describes the general characteristics of the respondents, among forty-two (42) respondents studied in the selected forest fringe communities. The male representation was $(55 \%, n=23)$ as compared to $(45 \%, n=19)$ females as depicted in table one. Male respondents formed large number interviewed in the selected communities due to the fact that they were more interested in forest related issues. Moreover, they largely participated in previous forest management programmes such as UNDP/SECA and Promoting Agriculture Governance and the Environment (PAGE) projects and the District Forestry Office (DFO) activities in the KHNFR than females. It shows a positive indication that implementation of forest reserve management plan was effectively followed since the male were heads of the family and therefore can easily influence the rest of the family to rally behind the programme although a few female households existed. Majority of the respondents $(55 \%, \mathrm{n}=23)$ falls within the age bracket of 33-39 years while $(12 \%, \mathrm{n}=5)$ of the respondents were above forty years. The other $(14 \%, \mathrm{n}=6)$ falls within the age bracket of $18-25$ years. It shows clearly that the youthful population who were more energetic were actively involved in the participatory approach used in managing the KHNFR. The youths in the study communities as indicated shows that they were concerned with the management and conservation of the reserve. It sends a clear picture on the minds of conservationist and other stakeholders in the field of environment because it ensures the sustainability of the system and above all the management of the forest reserve. This is ascertained in a report by UNDP/SECA and PAGE projects 
undertaken in the selected communities who were engaged in income generation from the resources of the forest. It was discovered that $(40 \%, \mathrm{n}=17)$ of the respondents had Junior School education, $(19 \%, \mathrm{n}=8)$ had Senior Secondary School Education. However, $(10 \%$, $\mathrm{n}=4)$ had Tertiary education and $(31 \%, \mathrm{n}=13)$ had no formal education. During discussion, it was revealed that they higher percentage of the respondents were those that had had basic education but could not further for various reasons. Reasons given bordered around inadequate funds, poor socio-economic background and above all, distance to cover to communities where higher institutions were established. Very few felt bitter and frustrated with their present conditions because they stopped schooling for no apparent reason rather than delinquency and inadequate support from parents or guardian. In totality the illiteracy rate of the respondents though low, was not much of an issue because they could understand some forest policy statements, implications and decisions taken bordering around forest sustainability, management and conservation. With their level of education, they could disseminate forest management information to other community members within the selected forest communities. Respondents' occupation were $(74 \%, \mathrm{n}=31)$ into farming, $(7 \%, \mathrm{n}=3)$ into trading while $(19 \%, \mathrm{n}=8)$ into varied types of occupation within the selected communities. It is succinct that farming is the main source of livelihood in the selected communities. The result shows that the study communities' livelihoods were mainly dependent on the KHNFR and therefore they would become poorer if prevented from accessing the forest reserve.

3.2 Forest Reserve Management Strategies Engaged In Khnfr.

\begin{tabular}{|l|l|l|l|l|l|}
\hline Variable & $\begin{array}{l}\text { Strongly } \\
\text { Disagree }\end{array}$ & Disagree & Nuetral & Agree & $\begin{array}{l}\text { Strongly } \\
\text { Agree }\end{array}$ \\
\hline $\begin{array}{l}\text { KHNFR has a } \\
\text { management plan }\end{array}$ & 4 & 10 & 3 & 7 & 18 \\
\hline DFO follows & 25 & $(10 \%)$ & $(7 \%)$ & $(17 \%)$ & $(42 \%)$ \\
\hline
\end{tabular}




\begin{tabular}{|c|c|c|c|c|c|}
\hline $\begin{array}{l}\text { prescriptions/items on } \\
\text { management plan }\end{array}$ & $(60 \%)$ & $(19 \%)$ & $(5 \%)$ & $(9 \%)$ & $(7 \%)$ \\
\hline $\begin{array}{l}\text { DFO contract } \\
\text { boundary cleaning } \\
\text { involves stakeholders }\end{array}$ & $\begin{array}{l}28 \\
(66 \%)\end{array}$ & $\begin{array}{l}7 \\
(17 \%)\end{array}$ & $\begin{array}{l}2 \\
(5 \%)\end{array}$ & $\begin{array}{l}3 \\
(7 \%)\end{array}$ & $\begin{array}{l}2 \\
(5 \%)\end{array}$ \\
\hline $\begin{array}{l}\text { DFO involved } \\
\text { community groups in } \\
\text { income generating } \\
\text { activities }\end{array}$ & $\begin{array}{l}2 \\
(5 \%)\end{array}$ & $\begin{array}{l}6 \\
(14 \%)\end{array}$ & $\begin{array}{l}3 \\
(7 \%)\end{array}$ & $\begin{array}{l}5 \\
(12 \%)\end{array}$ & $\begin{array}{l}26 \\
(62 \%)\end{array}$ \\
\hline $\begin{array}{l}\text { Private economic } \\
\text { activities are } \\
\text { established and } \\
\text { ongoing in KHNFR }\end{array}$ & - & - & $\begin{array}{l}2 \\
(5 \%)\end{array}$ & $\begin{array}{l}3 \\
(7 \%)\end{array}$ & $\begin{array}{l}37 \\
(88 \%)\end{array}$ \\
\hline
\end{tabular}

SOURCE: Field Data, 2021

Table two: KHNFR management strategies

This area identifies and shows some reserve management strategies in managing KHNFR in Kenema District. Data gathered from the study communities indicated that $42 \%$ strongly agreed that KHNFR has a management plan and $17 \%$ also agreed but indicated that it has become obsolete. For the very fact that they agreed that there was KHNFR management plan in the study communities, it should be noted as fact regardless its current status. If eighteen and seven respondents totaling twenty-five agreed that there was a management plan for KHNFR, then it is worth to go by because they were in majority. However, 24\% disagreed that there was KHNFR management plan while $10 \%$ also strongly disagreed. In the same vein, $7 \%$ took a neutral position on the grounds that they were not aware of any projects/activities going on in the reserve.

It was discovered that the first and only outstanding KHNFR Management Plan was development by PAGE which was later modified by UNDP/SECA from 2010-2014. Since then there has been no management plan for the forest reserve. However, it was generally 
accepted by majority of the respondents that District Forestry Office (DFO) has developed Kambui Hills Forest Management Plan taken cognizance of the previous one. The new management plan outlined various forest management strategies to be implemented in the reserve. When asked whether DFO was following all the items as enshrined in the KHNFR management plan in the process of managing the reserve in the selected communities, twenty-five of the respondents representing $60 \%$ strongly disagreed and eight of them representing 19\% disagreed forming a general disagreement of majority of the respondents indicated that DFO was not using the items enshrined in the KHNFR management plan. On the contrary, three of the respondents representing 7\% strongly agreed while four of them agreed that DFO was following the prescriptions on the management plan developed for KHNFR. However, two of the respondents representing 5\% remained neutral on the issue. The respondents who strongly agreed and agreed did that on a point that one company has started harvesting and maintenance of some few modified trees such as "Laphira alata and Parinari excela" stands in the forest reserve. This is diverse and difficult to conclude as forest communities lacked adequate information which was the fears of Kotey et al. (1998). It is also in disagreement with (Kotey, et al., 1998) as they recommended a better participation and involvement of forest communities and or groups in forest management. According to the data on table two, twenty-eight of the respondents representing $66 \%$ strongly disagreed that DFO contract boundary cleaning involves stakeholders and 7 of them representing $17 \%$ disagreed which forms the majority of the respondent who were not happy because DFO initially contacted them and also engaged them in the boundary cleaning exercise but later abandoned them. This made some area of the boundaries remained unattended as the stakeholders also abandoned the cleaning exercises. Three of the respondents agreed representing $7 \%$ while two of them strongly agreed and also two took neutral posture on the matter. Discussions revealed that the very few who were in agreement were benefitting extra 
favours from the project and DFO unit and therefore were unable to come up with the correct picture of the situation in the reserve. A few of the respondents were in disagreement because they had no cordial relationship with DFO and other environmental organizations. However, there was conflict over boundaries between community forest and KHNFR as community people accused DFO of claiming their community forest while the DFO on the other accused the forest community people of encroachment into the forest reserve. Although the previous work of UNDP/SECA and PAGE from 2010-2014 projects is critical here, but it was prudent for DFO to have better educated the community groups of the projects from its inception to completion. The DFO, UNDP/SECA and PAGE failed the forest communities as regulators for the fact that the respondents claimed to would have been abandoned. This was in total agreement with Brown (2000) who suggested that once the stakeholders have been identified, equitable partnership must have been established. This would have kept the stakeholders comfortable with their roles and responsibilities in the project.

Observation made by all the respondents pointed to the fact that they were not involve in the full implementation of these strategies. The very few who were initially engaged by UNDP/SECA and PAGE project in the formulation of the reserve management plan were left unattended to in one way or the other. This confirms (Blomley, 2013) who stated that forest community peoples full participation becomes difficult if it has no legal rights. 
Respondents were further asked whether they were involved in any income generating (IGAs) in the selected communities; twenty-six of the respondents representing $62 \%$ strongly agreed and five of them representing $12 \%$ agreed forming majority of them accepting the fact that they were involved in IGAs in their communities. This high response came up because the respondents claimed that they were part of the community group members who engage themselves in some Income Generation Activities (IGAs) by UNDP/SECA and PAGE projects in one way or the other. Unfortunately, the IGAs were no longer in existence in all the selected forest communities as the projects folded up. However two of the respondents representing $5 \%$ and six of them representing $14 \%$ disagreed while three of them representing $7 \%$ were neutral on the issue of IGA. Most the IGAs were neglected while others were destroyed leaving the environment bare and the forest communities poorer. For example, nursery sites at Gegeru and Menima communities planted with fruits to be marketed in the city for their livelihoods in the buffer zones were no longer in existence. Again respondents were asked whether economic activities were established and ongoing in the KHNFR, thirtyseven of the respondents representing $88 \%$ strongly agreed, three of the respondents representing 7\% agreed that there were economic activities established and ongoing in KHNFR while two of them representing 5\% took a neutral position. A good number of the respondents stated that DFO engaged private plantation and gold miners behind the scene which was detrimental to the management of the forest reserve. It also conclude that apart from DFO engaging some community groups members in the selected communities, other private plantation developers, loggers and gold miners were involved in exploiting the KHNFR. What worsens the situation was the fact that the community facilitators for the various projects who acted as liaison between DFO, the UNDP/SECA, PAGE and the selected communities were laid off when the project came to an end. This generated negative consequences particularly among the respondents which led to the increase of illegal logging; 
gold mining and other forms of illegal activities in the KHNFR that were environmental unfriendly. For sustainability in the KHNFR to prevail, there should be transparency from DFO and empowerment of forest communities which is in line with Fomete (2001) who opines that there is a need for stronger legal institutions to entrench community groups' roles in forest reserve management.

3.3 Stakeholders Participation in Khnfr Management

\begin{tabular}{|c|c|c|c|c|c|}
\hline VARIABLE & $\begin{array}{l}\text { STRONGLY } \\
\text { DISAGREE }\end{array}$ & DISAGREE & NUETRAL & AGREE & $\begin{array}{l}\text { STRON } \\
\text { GLY } \\
\text { AGREE }\end{array}$ \\
\hline $\begin{array}{l}\text { DFO involved } \\
\text { community groups in } \\
\text { managing KHNFR }\end{array}$ & $\begin{array}{l}34 \\
(81 \%)\end{array}$ & $\begin{array}{l}2 \\
(5 \%)\end{array}$ & $\begin{array}{l}1 \\
(2 \%)\end{array}$ & $\begin{array}{l}5 \\
(12 \%)\end{array}$ & - \\
\hline $\begin{array}{l}\text { DFO had assigned } \\
\text { community groups' } \\
\text { roles in managing } \\
\text { KHNFR }\end{array}$ & $\begin{array}{l}18 \\
(43 \%)\end{array}$ & $\begin{array}{l}12 \\
(28 \%)\end{array}$ & $\begin{array}{l}3 \\
(7 \%)\end{array}$ & $\begin{array}{l}5 \\
(12 \%)\end{array}$ & $\begin{array}{l}4 \\
(10 \%)\end{array}$ \\
\hline $\begin{array}{l}\text { DFO involved } \\
\text { community groups as } \\
\text { stakeholders in } \\
\text { decision making and } \\
\text { formulation of } \\
\text { KHNFR management } \\
\text { plan }\end{array}$ & $\begin{array}{l}3 \\
(7 \%)\end{array}$ & $\begin{array}{l}5 \\
(12 \%)\end{array}$ & $\begin{array}{l}4 \\
(10 \%)\end{array}$ & $\begin{array}{l}6 \\
(14 \%)\end{array}$ & $\begin{array}{l}24 \\
(57 \%)\end{array}$ \\
\hline $\begin{array}{l}\text { DFO involved } \\
\text { community groups in } \\
\text { implementation of } \\
\text { KHNFR management } \\
\text { plan }\end{array}$ & $\begin{array}{l}31 \\
(73 \%)\end{array}$ & $\begin{array}{l}4 \\
(10 \%)\end{array}$ & $\begin{array}{l}5 \\
(12 \%)\end{array}$ & $\begin{array}{l}2 \\
(5 \%)\end{array}$ & - \\
\hline $\begin{array}{l}\text { Community groups } \\
\text { are involved benefit } \\
\text { sharing of proceeds }\end{array}$ & $\begin{array}{l}30 \\
(71 \%)\end{array}$ & $\begin{array}{l}10 \\
(24 \%)\end{array}$ & $\begin{array}{l}2 \\
(5 \%)\end{array}$ & - & - \\
\hline
\end{tabular}




\begin{tabular}{|l|l|l|l|l|l|}
\hline from KHNFR & & & & & \\
\hline $\begin{array}{l}\text { DFO involved } \\
\text { community groups in } \\
\text { making activities } \\
\text { ongoing in KHNFR }\end{array}$ & $35 \%)$ & 4 & 3 & - & - \\
\hline
\end{tabular}

SOURCE: Field Data, 2021

Table three: forest communities' participation

Respondents were further asked as to whether they were involved in the management of the KHNFR in their communities during the implementation of various projects; thirtyfour of the respondents representing $81 \%$ strongly disagreed and two of them representing $5 \%$ disagreed which comprises bulk of the respondents. However, five of them representing $12 \%$ agreed that they were involved in the management of the KHNFR while one of them representing $2 \%$ remained neutral on the issue. This was not in line with government policy (Environmental Protection Agency Act of Sierra Leone, 2009) which recognizes that forest communities could be more effective and efficient at executing certain forest task. It is succinct that DFO has not considered forest community groups to play a pivotal role in managing KHNFR. The Environmental Protection Agency Act of Sierra Leone Sierra Leone, 2009 acknowledges the facts that natural forest were being depleted by moment and therefore raised concern for its protection and management so that the remaining biodiversity, soil and water resources would be conserved for future generation. The forest is to be completely protected for conservation purposes. This can be effective and efficiently done when the policy is enforced in the area of partnering with forest community groups and or people in the protection and management of the reserve sectors. The respondents were asked whether District Forestry Office (DFO) did assign any of them in the study communities to play management role in the KHNFR, $43 \%$ strongly disagreed and $28 \%$ disagreed. Bulk of the respondents indicated that they were not involve in taken any managerial role in the KHNFR. 
$12 \%$ agreed, $10 \%$ strongly agreed while $7 \%$ remained neutral on the issue. A few agreed that they were involved and participated but at low key. This clearly shows that DFO, UNDP/SECA and PAGE did not consider much participation of stakeholders in the management of the reserve. It should be noted that collaborative forest management is a bottom- top approach where in communities in and around forest reserves are actively involved in the management and protection of the forest resources. Management goes beyond controlling people to achieve a set goal. In this context management involves recognition of the need to integrate conservation and sustainable development of forest reserve. It captures the legitimacy of the rights of the local forest communities to secure their socio-economic feature through their active involvement in forest conservation and management. Respondents indicated that DFO involved community groups as stakeholders in decision making and formulation of KHNFR management plan as 57\% strongly agreed and 14\% agreed that they had some interactions with UNDP/SECA, PAGE AND DFO during the implementation of various projects in the forest reserve but they were not sure whether their inputs were taken into consideration. Three of the respondents representing $7 \%$ disagreed and five of them representing $12 \%$ disagreed that the organizations and DFO involved them while $10 \%$ remained neutral. Their disagreement was based on the facts that they had no technical knowledge and were not knowledgeable with the activities of the organizations and DFO. It was also indicated that they had no knowledge about forest reserve management planning. This clearly indicates that there was much awareness raising strategies among the community groups with regards the formulation of the forest management plan in the selected communities. What poses problem was limited capacity and skill training of the community groups /stakeholders which would have enhanced effectiveness, efficiency and equity. $73 \%$ of Community groups strongly disagreed and $10 \%$ disagreed that they were involved in the implementation of KHNFR management plan. However, 5\% agreed that they were involved 
while $12 \%$ maintained neutral grounds. This clearly depicts a picture of neglect and as a result, the community groups were left on their own unattended when the projects were handed over to DFO in Kenema District. The study however pointed in the negative when majority of the respondents and stakeholders arguably disagreed with their involvement in the management of KHNFR. From the table above, thirty of the respondents representing $71 \%$ strongly disagreed together with other ten respondents representing $24 \%$ also disagreed that community groups were involved in benefit sharing of all proceeds from KHNFR. It was an irony as the remaining two respondents representing 5\% did not know anything about benefits or proceed sharing from the forest reserve. This explains that there is no equity between DFO and the forest community groups because the government did not give legal rights to community groups over the resources of reserve forest in Sierra Leone. This had negative impact on the community groups in the selected study communities as their involvement in forestry projects and forest management was less. To the worst they were used as labourers in project activities in the KHNFR.

There is a need to encourage partnerships and tackle environmental issues such as how the community relationship should be cultivated by organizations and DFO from raw deals to mutual gains. Community groups were looking for partnerships with relevant and trust worthy stakeholders as a way forward as it was captured by Asare (2001) who suggested that community groups must be granted local licensing and revenue sharing in the forest reserve area. Again $83 \%$ of the respondents strongly disagreed and also $10 \%$ disagreed that they were not involve in monitoring of any ongoing activity in KHNFR. However, 7\% remained neutral. Therefore the negative consequences included connivance and abetting attitude of some community groups in committing all forms of illegal activities ranging from illegal gold mining to logging. Bulk of the respondents stated that they were involved in decision making during the implementations of UNDP/SECA and PAGE projects. They were 
involved in focus group discussions and road mapping for the development of the management plan but were not involved in the implementation of the projects in the reserve. This also support the work of Kotey et al. (1998) who postulated that people's participation therefore demands that forest fringe communities should be involved in all decision making bordering around the management and sustainable development of their reserve forest. This would improve their comprehension and above all commitment to the natural resource development and protection by them. In the same vein, the result agree s with FAO's (2010) contention that forestry exist when the local community in that area plays an important role in land use decision making. This is because when the community people are satisfied, with their involvement, benefits and participation then sustainable forest management and its resources would be guaranteed

3.4 Types of Livelihood Activities Involved By the Forest Communities in Khnfr Management.

This area clearly shows the type of livelihood activities engaged in by forest communities in managing KHNFR in Kenema District.

\begin{tabular}{|c|c|c|c|c|c|}
\hline VARIABLE & $\begin{array}{l}\text { STRONGLY } \\
\text { DISAGREE }\end{array}$ & DISAGREE & NUETRAL & AGREE & $\begin{array}{l}\text { STRON } \\
\text { GLY } \\
\text { AGREE }\end{array}$ \\
\hline $\begin{array}{l}\text { Fruits plantation } \\
\text { established in } \\
\text { community forest } \\
\text { and around KHNFR }\end{array}$ & $\begin{array}{l}30 \\
(71 \%)\end{array}$ & $\begin{array}{l}3 \\
(7 \%)\end{array}$ & $\begin{array}{l}5 \\
(12 \%)\end{array}$ & $\begin{array}{l}4 \\
(10 \%)\end{array}$ & - \\
\hline $\begin{array}{l}\text { Nursery sites } \\
\text { established in } \\
\text { community forest } \\
\text { and around KHNFR }\end{array}$ & $\begin{array}{l}7 \\
(17 \%)\end{array}$ & $\begin{array}{l}5 \\
(12 \%)\end{array}$ & $\begin{array}{l}3 \\
(7 \%)\end{array}$ & $\begin{array}{l}15 \\
(36 \%)\end{array}$ & $\begin{array}{l}12 \\
(28 \%)\end{array}$ \\
\hline $\begin{array}{l}\text { Soap making by } \\
\text { community women }\end{array}$ & $\begin{array}{l}30 \\
(71 \%)\end{array}$ & $\begin{array}{l}3 \\
(7 \%)\end{array}$ & $\begin{array}{l}2 \\
(5 \%)\end{array}$ & $\begin{array}{l}7 \\
(17 \%)\end{array}$ & - \\
\hline
\end{tabular}




\begin{tabular}{|c|c|c|c|c|c|}
\hline established by DFO & & & & & \\
\hline $\begin{array}{l}\text { Improved animal } \\
\text { husbandry } \\
\text { established for } \\
\text { community groups }\end{array}$ & $\begin{array}{l}35 \\
(83 \%)\end{array}$ & $\begin{array}{l}3 \\
(7 \%)\end{array}$ & $\begin{array}{l}2 \\
(5 \%)\end{array}$ & $\begin{array}{l}2 \\
(5 \%)\end{array}$ & - \\
\hline $\begin{array}{l}\text { DFO allowed } \\
\text { community members } \\
\text { to collect NTFP in } \\
\text { KHNFR }\end{array}$ & - & - & $\begin{array}{l}3 \\
(7 \%)\end{array}$ & $\begin{array}{l}8 \\
(19 \%)\end{array}$ & $\begin{array}{l}31 \\
(74 \%)\end{array}$ \\
\hline
\end{tabular}

SOURCE: Field Data, 2021

Table four: Livelihood activities

Respondents were asked whether fruits plantation was established in the community forest and around KHNFR, thirty respondents representing $71 \%$ strongly disagreed and three of them agreed forming majority. Five of the respondents representing $12 \%$ maintained neutrality on the issue while four of them representing $10 \%$ agreed. There was high number of respondents who disagreed due to the fact that UNDP/SECA and PAGE projects actually involved them in planting various fruits both in the community forest and around the KHNFR but were burnt down by wild fire in the dries when handed over to DFO. Since then the plantation was never replanted which had negative implication on the economic status of the selected communities as it had impact on their income generating prospect. Again when asked whether nursery sites were established in community forest and around KHNFR fifteen respondents representing 36\% agreed and twelve of them representing $28 \%$ strongly agreed which forms the majority. It was discovered during discussions that most of the nursery sites were raided by thieves who uprooted hundreds of viable economic plants. Seven of the respondents representing $17 \%$ strongly disagreed, five of them representing $12 \%$ agreed while three of them representing 7\% maintained a neutral ground. Their own communities could not maintain nursery sites established as it immediately stopped existing when it was 
handed over to DFO. Respondents were further asked whether soap making by women in the study communities by DFO was established; thirty of the respondents representing $71 \%$ strongly agreed and three of them representing $7 \%$ disagreed summing up to thirty-three respondents out of forty-two. The respondents vividly expressed their views that soap making was indeed established for women by both UNDP/SECA and PAGE projects in all the selected communities but collapsed after few months due to lack of entrepreneurial skills. Seven of the respondents representing $17 \%$ agreed whilst two of them representing $5 \%$ remained neutral. Moreover, a few respondents indicated that improved animal husbandry was established for community groups in the selected communities UNDP/SECA and PAGE projects, $83 \%$ strongly disagreed and $7 \%$ also disagreed. In the same vein, $5 \%$ agreed and $5 \%$ also remained neutral. The respondents expressed a view that it was a good initiative but collapsed as the projects folded up. However, 74\% strongly agreed and 19\% agreed that they were allowed to collect Non Timber Forest Products (NTFPs) in the KHNFR whilst 7\% remained neutral. Apart from the NTFPs, other forest reserve products were also collected from the reserve which included mushrooms, mango, pineapple, stones etc. This captures the work of Brown (2000) who observed that collaboration in whatever form involves two way; either exchange of experience and knowledge in partnership between the local people and forestry or working partnership between the local people and the government. This same observation was expressed by Kotey et al (1998) as they revealed that collaboration in utilizing forest resource needs to come as concerted effort between the forest communities and DFO. Never the less, the respondents had an optimistic view that any other livelihood activity that may involve them by an organization would go a long way in protecting the forest from illegal activities in their localities. Based on the study in the selected forest communities, there was weak collaboration between the community people and the forest authorities especially DFO which made it too difficult to incorporate the local forest 
communities in forest management programmes/projects and communicate well with them on forest management. Majority of the respondents were in quest for a need of other viable and sustainable livelihood activities in their communities so that sustainable forest management would be realized as they would focus on their livelihood assets other KHNFR. It is evident that the results support Blomley et al. (2009) assertion that the integration of livelihood activities for forest community groups in sustainable forest management provides wider opportunities in resource utilization. It also reduces unnecessary risk and provides additional food and income for the rural poor.

\subsection{Conclusion and Recommendations}

There has been several government policies, acts and regulations on forest management, conservation and protection in Sierra Leone since the 1980s and various types of strategic plans and interventions coupled with policy reforms have been passed and are still ongoing in the country. These policies, regulations and acts are affected by illegal persons who are bent in reducing the forest reserve to its lowest ebb. The forest fringe community groups or members in the KHNFR had a conviction that the forest reserve is changing its natural vegetation from tropical to grassland due to constant depletion of the reforest. The forest communities were also aware of the fact that uncontrolled and further depletion of the forest reserve would negatively affects them. Therefore they were willing to help in the proper management of the forest reserve in their localities. For them, this could be done through their total involvement, partnership and regular consultation from the DFO. In the same vein, the study also took cognizance of the fact that community groups or members were readily willing to assist in the management of the forest reserve and it was demonstrated highly in the co-management plan interrelationship created during the development of the KHNFR management plan developed together with PAGE. Therefore there is a need to critically look at various policies, acts, regulations, plans and strategies in sustainable forest management of 
forest reserve through a supply chain perspective lens. In that regard therefore the study recommends the following for implementation:

- DFO to integrate community forestry management and protection groups in all forest reserve fringe communities.

- Authorities particularly DFO, Environmental Protection Agency Sierra Leone and Environmental Organizations try to gain and win the minds and hearts of forest community groups or members by constantly engaging them in various forest management and protection processes. This could be done through forest guards, extension services unit who would serve as liaison between the DFO and the forest communities.

- More importantly, community members should be empowered through training to serve as co-managers of the reserve forest by empowering them to arrest and even cease forest products harvested illegally from the reserve with a handsome reward in cash or in kind.

- Also empower forest community co-managers to visit other African countries so as to experience various sustainable community forest management projects.

- Provide support to community groups or members with capital so that they could expand their livelihood sources and or assets

- Provide value chain market opportunity for forest fringe communities to reduce their dependence on the forest reserve

- Forest guards, Rangers, Range Supervisors to be adequately equipped and trained backed by improved interpersonal relationship with forest reserve communities

- There should also be regular visit and collegial interaction between DFO and forest fringe communities because they are the strongest link in the supply chain for managing the natural resources of the forest reserve. 


\section{References}

Asare, A. (2000). Community Involvement in Forest Management: The Experience of the Forestry Services Division of Ghana. Kumasi: CFMU.

Brown, D. (2000). The Gambian-German Forestry Project. In D. Brown, M. Howes, K. Hussein, C. Longley, \& K. Swindell (Eds.), Participation in Practice: Case Studies from the Gambia (2002, pp. 147-189). London: Overseas Development Institute.

Birdlife IBA Factsheet (2007). Kambui Hills Forest Reserve. Birdlife International. Retrieved..........

Blinker, Leslie (2006). The country Environmental profile [CEP] Sierra Leone.

Blomley, T., \& Franks, P. (2009). Making Participatory Forest Management Work for the Poor. A review of Tanzanian and Nepali Experiences with Recommendations for Policy Makers and Field-Level Practitioners. Copenhagen: CARE Denmark.

Blomley, T., Lukumbuzya, K., \& Brodnig, G. (2011). Participatory Forest Management and REDD+ in Tanzania. Washington, DC: World Bank.

Blomley, T. (2013). Lessons Learned from Community Forestry in Africa and Their Relevance for REDD+. USAID-Supported Forest Carbon, Markets and Communities (FCMC) Program, Washington, DC.

Community Forestry in Namibia (CFN) (2008). Forests for People. Visions, Facts and Figures. Frankfurt: BMZ/KfW Germany.

Draft forest Act (2011). Government of Sierra Leone (GoSL).

Draft Kambui North Reserve Co-Management Plan (2012).

FAO (2010). Global Forest Resource Assessment Key Finding. Sierra Leone: FAO.

Fomete, T. (2001). The Forestry Taxation System and the Involvement of Local Communities in Forest Management in Cameroon. ODI RDFM Paper No. 25b, London: ODI. Forest Regulations (1990). Government of Sierra Leone (GoSL). Forest Regulatary. 
Forest Regulations (1990). Government of Sierra Leone (GoSL).

Forest Policy (2011). Government of Sierra Leone (GoSL).

Forest Ordinance of Sierra Leone (1912). Government of Sierra Leone (GoSL). Order 8, Section 4-13

Kotey, E. N. A., Francois, J., Owusu, J. G. K., Yeboah, R., Amanor, K. S., \& Antwi, L. (1998). Falling into Place. Police That Work for Forests and People Series No. 4. London: International Institute for Environment and Development.

The Forestry Act (1988). Government of Sierra Leone (GoSL). Vol.CX1XX, No.38

The Rural Area Act (1990). Third Schedule, Amendment Order. Government of Sierra Leone (GoSL).

UNDP/SECA (2013). Exploring Socio-Economic Livelihood Activities of Fringe Communities within Kambui Hills North Forest Reserves in Kenema District.

World Bank (2002).A Revised Forest strategy for the World Bank Group Washington DC. Washington, DC: World Bank.

World Database on Protected areas Achieved (2007). UN Environment Programme World Conservation Monitoring Centre. Retrieved 02/02/2021. 